\title{
Anaerobic bacteria and herpes simplex virus in genital ulceration
}

\author{
A N MASFARI,* G R KINGHORN, † S HAFIZ,* I G BARTON, \# AND \\ B I DUERDEN* \\ From the Departments of ${ }^{*}$ Medical Microbiology and $\$$ Virology, University of Sheffield Medical School, \\ and + Department of Genitourinary Medicine, Royal Hallamshire Hospital, Sheffield
}

SUMMARY Of 91 patients with genital ulceration, herpes simplex virus was isolated from 52 (57\%) and Haemophilus ducreyi from $12(13 \%)$; none had syphilis. The difference in incidence of other aerobes in patients and controls was not significant. Anaerobes, predominantly Bacteroides spp, were isolated from a large proportion $(\mathbf{7 7 \%})$ of men and women patients with ulcers but from few control men. The most common anaerobic species were $B$ asaccharolyticus and $B$ ureolyticus, with fewer isolates of the melaninogenicus/oralis group. The bacterial flora of herpetic and nonherpetic ulcers were similar, but Candida albicans was isolated significantly more often from nonherpetic ulcers. Anaerobic bacteria may contribute to the pathogenesis of genital ulcers.

\section{Introduction}

Non-treponemal genital ulcers have become increasingly common in England. ${ }^{1}$ Genital herpes accounts for $40-80 \%$ of uicers in developed countries but only $5-11 \%$ in developing countries. ${ }^{2-6}$ This contrasts with a prevalence in developing countries of $42-62 \%$ for the other major infectious cause of genital ulceration, Haemophilus ducreyi, which accounts for only $1-2 \%$ in the United States. ${ }^{4}$ In 1982 we reported a high incidence (29\%) of $H$ ducreyi in genital ulcers in Sheffield, often in association with genital herpes. 5 Various other aerobic bacterial pathogens (such as Staphylococcus aureus and $\beta$-haematolytic streptococci) have been isolated from a small proportion of patients. Since the early reports of Fournier ${ }^{7}$ and Meleney, ${ }^{8}$ anaerobic bacteria have been recognised in phagedenic ulcers of the genitalia, especially those associated with poor hygiene. Investigations of anaerobic bacteria, however, have been inadequate in many studies. When conventional diagnostic methods were used in Sheffield, anaerobes were isolated from only $6 \%$ of ulcers and were always associated with other known pathogens of ulcers. ${ }^{5}$ In 1978, Chapel et al used more sophisticated techniques to show the polymicrobial aetiology of genital ulcers; anaerobic bacteria were present in

Address for reprints: Professor B I Duerden, Department of Medical Microbiology, The University of Sheffield Medical School, Beech Hill Road, Sheffield S10 2RX

Accepted for publication 4 July 1984
$64 \%$ of ulcers in men, but their presence was not related to the pathogenesis of the lesions. ${ }^{9}$

The study reported here was performed to assess a possible role of anaerobic bacteria, alone or in association with other pathogens, in genital ulcers.

\section{Patients and methods}

\section{PATIENTS}

We studied 91 patients (46 men and 45 women) randomly selected from those attending the department of genitourinary medicine of the Royal Hallamshire Hospital, Sheffield, with ulcerative lesions of the external genitalia. Table I shows the demographic data of these patients, who were typical of the clinic population in being predominantly young, heterosexual, white, and unmarried. Of 32 patients with a history of sexually transmitted disease (STD) (13 men and 19 women), seven had had preceding episodes of genital ulceration caused by herpes simplex virus (HSV) but none had a history of syphilis or chancroid.

A series of 24 men with no clinical evidence of genital tract infection, who had been studied within the preceding year, ${ }^{10}$ served as controls for the men patients with ulcerative lesions. The demographic data for the 24 controls were similar to those for patients with ulcerative lesions (table I).

\section{COLLECTION OF SPECIMENS}

We performed the following investigations routinely on all patients with genital ulcers. The patients were 
TABLE I Demographic details of patients and control men

\begin{tabular}{|c|c|c|c|}
\hline Demographic character & $\begin{array}{l}\text { Men } \\
(n=46)\end{array}$ & $\begin{array}{l}\text { Women } \\
(n=45)\end{array}$ & $\begin{array}{l}\text { Control men } \\
(n=24)\end{array}$ \\
\hline $\begin{array}{l}\text { Mean (range) } \\
\text { years old }\end{array}$ & $27 \cdot 0(17-42)$ & $21 \cdot 8(15-37)$ & $27 \cdot 4(22-49)$ \\
\hline $\begin{array}{l}\text { Marital state: } \\
\text { Single } \\
\text { Married }\end{array}$ & $\begin{array}{l}30 \\
16\end{array}$ & $\begin{array}{r}37 \\
8\end{array}$ & $\begin{array}{r}18 \\
6\end{array}$ \\
\hline $\begin{array}{l}\text { Race: } \\
\text { White } \\
\text { Black } \\
\text { History of STD } \\
\text { History of } \\
\text { genital herpes }\end{array}$ & $\begin{array}{r}44 \\
2 \\
13 \\
4\end{array}$ & $\begin{array}{r}44 \\
1 \\
19 \\
3\end{array}$ & $\begin{array}{r}23 \\
1 \\
10\end{array}$ \\
\hline
\end{tabular}

seen by three members of the clinical staff who applied standard procedures of clinical examination and collection of specimens. Exudate from the bases of the ulcers was collected on three cotton wool swabs; one was inserted into charcoal Amies's transport medium ${ }^{11}$ to isolate aerobic and anaerobic bacteria, the second was inserted into virus transport medium to isolate HSV, and the third was used immediately to inoculate two plates of Sheffield medium, one of which contained $5-7 \%$ horse blood, ${ }^{12}{ }^{13}$ to isolate $H$ ducreyi.

The specimens for bacteriological examination were kept at room temperature and transferred to the department of medical microbiology, where they were processed within two hours of collection. Those for virological culture were kept in the clinic refrigerator before transfer within four hours of collection to the department of virology, where they were stored at $-70^{\circ} \mathrm{C}$.

After these swabs had been taken, the lesions were cleansed with saline and abraded to obtain exudate for dark field microscopy examination for Treponema pallidum. The Venereal Disease Research Laboratory (VDRL) test and the $T$ pallidum haemagglutination assay (TPHA) for syphilis were performed on serum from all patients.

The controls were seen by the same three members of the clinical staff. Urethral and subprepucial swabs were taken for culture of aerobic and anaerobic bacteria as described previously, ${ }^{10}$ and blood was collected for serological tests for syphilis.

\section{LABORATORY INVESTIGATIONS}

Isolation of herpes simplex virus $H S V$

The specimen was inoculated on to confluent monolayers of human embryo fibroblasts, which were incubated at $37^{\circ} \mathrm{C}$ for up to 14 days and observed daily for the characteristic cytopathic effect of HSV.

\section{Isolation of $\boldsymbol{H}$ ducreyi}

The two plates of Sheffield medium were incubated in air with $5 \%$ carbon dioxide at $33^{\circ} \mathrm{C}$ for up to seven days, and strains of $H$ ducreyi were identified as described previously. ${ }^{5}$

\section{Aerobic and anaerobic culture}

The swab in Amies's medium was agitated and thoroughly squeezed out in $0.6 \mathrm{ml}$ peptone water (proteose peptone No 3, Difco). Two drops $(0.4 \mathrm{ml})$ of this suspension were seeded on to each of five plates: two blood agar plates (blood agar base No 2 (Oxoid) with 7\% defibrinated horse blood (Oxoid)), one plate of Sabouraud's agar (Oxoid), one of Rogosa agar (Oxoid), and one of bacteroides medium (BM) agar with kanamycin $75 \mathrm{mg} / \mathrm{l}$ (BMK) ${ }^{14}$ on which a $5 \mu \mathrm{g}$ metronidazole disc was placed for presumptive recognition of anaerobes. One blood agar plate, the Rogosa agar plate, and the BMK agar plate were incubated anaerobically; the other blood agar plate and the Sabouraud's agar plate were incubated aerobically. The conditions of incubation and the methods of isolation and identification of anaerobes and aerobes have been described previously. ${ }^{10}$

\section{Statistical analysis}

We used the $\chi^{2}$ test to compare the results obtained from men patients compared with controls and from men patients compared with women patients.

\section{Results}

Specimens from all patients were examined for the three established aetiological agents of genital ulceration: HSV, $T$ pallidum, and $H$ ducreyi. Table II shows that no patients or controls had syphilis, but HSV was isolated from $52(57 \%)$ patients with ulcers and $H$ ducreyi from $12(13 \%)$. The remaining 27 $(30 \%)$ patients yielded none of these established pathogens. The predominant bacterial flora in control men were aerobes, the isolation of which was significantly less common from men patients with ulcers $(\mathrm{p}=<0 \cdot 01)$. Candida albicans was isolated

TABLE II Microbial flora of patients with genital ulceration and control men

\begin{tabular}{|c|c|c|c|c|}
\hline \multirow[b]{2}{*}{ Microbial species } & \multicolumn{4}{|c|}{$\begin{array}{l}\text { No }(\%) \text { of subjects from whom the given } \\
\text { species was isolated: }\end{array}$} \\
\hline & $\begin{array}{l}\text { Men } \\
\text { controls } \\
(n=24)\end{array}$ & $\begin{array}{l}\text { Men } \\
\text { patients } \\
(n=46)\end{array}$ & $\begin{array}{l}\text { Women } \\
\text { patients } \\
(n=45)\end{array}$ & $\begin{array}{l}\text { All } \\
\text { patients } \\
(n=91)\end{array}$ \\
\hline $\begin{array}{l}\text { Herpes simplex virus } \\
\text { Treponema pallidum }\end{array}$ & & $25(54)$ & $27(60)$ & $52(57)$ \\
\hline $\begin{array}{l}\text { Haemophilus ducreyi } \\
\text { Other aerobic bacteria } \\
\text { Candida albicans } \\
\text { Anaerobic bacteria }\end{array}$ & $24(100)^{*}$ & $\begin{aligned} & 7(15) \\
& 32(70)^{*} \\
& 5(11) \\
& 33(72)^{* *}\end{aligned}$ & $\begin{array}{l}5(11) \\
30(67) \\
10(22) \\
37(82)\end{array}$ & $\begin{array}{l}12(13) \\
62(68) \\
15(16) \\
70(77)\end{array}$ \\
\hline
\end{tabular}

${ }^{*} \mathrm{p}<0.01 ;{ }^{* *} \mathrm{p}<0.001$. 
only from men patients with ulcers and not from control men, but the difference was not significant. The most signficant difference between men with ulcers and controls was the predominance of anaerobic bacteria $(p=<0.001)$. The results obtained from men and women patients with ulcers showed no significant differences.

TABLE III Aerobic flora of patients with genital ulcers and control men

\begin{tabular}{|c|c|c|c|c|}
\hline \multirow[b]{2}{*}{ Aerobic species } & \multicolumn{4}{|c|}{$\begin{array}{l}\text { No }(\%) \text { of subjects from whom the given } \\
\text { species was isolated: }\end{array}$} \\
\hline & $\begin{array}{l}\text { Men } \\
\text { controls } \\
\text { ( } n=24)\end{array}$ & $\begin{array}{l}\text { Men } \\
\text { patients } \\
(n=46)\end{array}$ & $\begin{array}{l}\text { Women } \\
\text { patients } \\
(n=45)\end{array}$ & $\begin{array}{l}\text { All } \\
\text { patients } \\
(n=91)\end{array}$ \\
\hline $\begin{array}{l}\text { Coagulase negative } \\
\text { staphylococci } \\
\text { Staphylococcus aureus } \\
\text { Coryneforms }\end{array}$ & $\begin{array}{l}24(100)^{* *} \\
24(100)^{* *}\end{array}$ & $\begin{array}{l}28(61)^{* *} \\
4(9) \\
25(54)^{* *}\end{array}$ & $\begin{array}{l}28(62) \\
2(4) \\
15(33)\end{array}$ & $\begin{array}{c}56(61) \\
6(7) \\
40(44)\end{array}$ \\
\hline $\begin{array}{l}\alpha \text {-haemoiytic } \\
\text { streptococci } \\
\beta \text {-haemolytic }\end{array}$ & $6(25)$ & $5(11)$ & $6(13)$ & $11(12)$ \\
\hline $\begin{array}{l}\text { streptococci } \\
\text { Enterobacteria } \\
\text { Lactobacilli }\end{array}$ & $1(4)$ & $1(2)$ & $\begin{array}{l}1 \text { ( }(2) \\
3(7) \\
9(20)^{*}\end{array}$ & $\begin{array}{l}1(1) \\
4(4) \\
9(10)\end{array}$ \\
\hline
\end{tabular}

${ }^{*} p<0 \cdot 01 ;{ }^{* *} p<0 \cdot 001$

\section{AEROBIC FLORA}

Table III shows the aerobic species isolated from patients and controls. The only significant differences were the greater prevalence of the normal skin commensals (coagulase negative staphylococci and coryneforms) in controls compared with men with ulcers controls, and the greater prevalence of the vaginal commensals (lactobacilli) in women with ulcers compared with men.

TABLE IV Anaerobic flora of patients with genital ulceration and control men

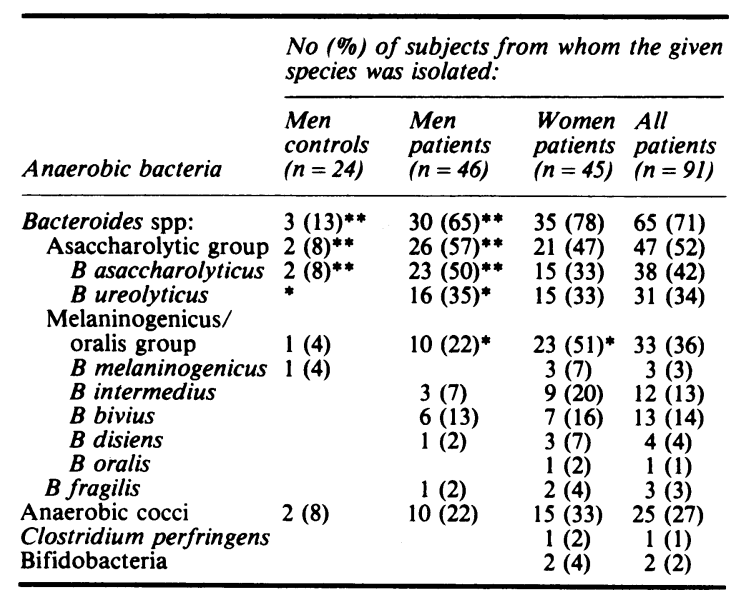

${ }^{*} \mathrm{p}<0.01 ;{ }^{* *} \mathrm{p}<0.001$.

\section{ANAEROBIC FLORA}

Table IV shows the anaerobic species isolated from patients and controls. Gram negative anaerobic bacilli (Bacteroides spp) were significantly more prevalent in men with ulcers than in controls $(\mathrm{p}=<0.001)$, because the asaccharolytic Bacteroides spp, $B$ asaccharolyticus and $B$ ureolyticus, were isolated from more men with ulcers. The differences between men with ulcers and controls in isolation of the melaninogenicus/oralis or fragilis groups of Bacteroides, or of clostridia, bifidobacteria, or the anaerobic cocci were not significant, although the latter (especially Gram positive cocci) were more common in patients than in controls. The prevalence of anaerobic bacteria in women with ulcers was generally the same as in men patients. The asaccharolytic Bacteroides spp were also common isolates in women patients, but so were species of the melaninogenicus/oralis group, which are part of the normal vaginal flora. ${ }^{15}$

\section{Microbial flora of herpetic and non-herpetic ulcers}

Table V shows the bacterial species isolated from 52 patients ( 25 men and 27 women) who had positive cultures for HSV and from 39 patients (21 men and 18 women) who were HSV culture negative. The differences in isolation of $H$ ducreyi, other aerobic bacteria, or anaerobic bacteria from the two groups was not significant. $C$ albicans was isolated in significantly more $(\mathrm{p}=\langle 0.01)$ patients who were HSV culture negative. $H$ ducreyi was isolated from three of the $12 \mathrm{HSV}$ negative patients who yielded $C$ albicans, but this proportion was no different from its overall prevalence in all the patients with ulcers.

\section{Discussion}

Recent studies in the United Kingdom have shown considerable variation in the proportion of ulcers

TABLE V Microbial flora of herpetic and non-herpetic ulcers

\begin{tabular}{lll}
\hline & $\begin{array}{l}\text { No (\%) of patients from } \\
\text { whom the given species } \\
\text { was isolated: }\end{array}$ \\
\cline { 2 - 3 } & $\begin{array}{l}\text { Negative } \\
\text { for HSV }\end{array}$ & $\begin{array}{l}\text { Positive } \\
\text { for HSV } \\
\end{array}$ \\
Microbial species & $n=39)$ & $n=52)$ \\
\hline Haemophilus ducreyi & $7(18)$ & $5(10)$ \\
Other aerobic bacteria & $26(67)$ & $34(65)$ \\
Candida albicans & $12(31)^{*}$ & $3(6)^{*}$ \\
Bacteroides spp & $25(64)$ & $40(77)$ \\
Asaccharolytic group & $18(46)$ & $29(56)$ \\
Melaninogenicus/oralis group & $11(28)$ & $22(42)$ \\
Fragilis group & $1(3)$ & $2(4)$ \\
Other anaerobic bacteria & $10(26)$ & $18(35)$ \\
\hline
\end{tabular}

${ }^{*} \mathrm{p}<0.01$.

$\mathrm{HSV}=$ herpes simplex virus. 
associated with the different recognised pathogens. Other workers have found HSV in $30-50 \%, T$ pallidum in 3-5\%, and $H$ ducreyi in 3-11\% of ulcers; and none of these pathogens in 42-65\%. ${ }^{16-18}$ In 1982 we found HSV in $81 \%, T$ pallidum in $1 \%, H$ ducreyi in $29 \%$, and no pathogens in $13 \%$ of a consecutive series of patients with genital ulcers attending all clinics in the department of genitourinary medicine at all times of day. ${ }^{5}$ In the present study of randomly selected patients, mostly attending morning clinics, we found a smaller proportion of HSV $(57 \%)$ and $H$ ducreyi $(13 \%)$ and a larger proportion $(30 \%)$ of patients with none of the recognised pathogens. These differences may reflect the different approach to patient selection but they still confirm a higher prevalence of HSV and $H$ ducreyi than has been found elsewhere. The results for $H$ ducreyi are probably partly because of the particularly careful methods used to isolate this organism. ${ }^{519}$ Samples from controls were not cultured for $\boldsymbol{H}$ ducreyi and HSV because the main consideration was to examine the prevalence of anaerobic bacteria. Although such investigations would have added strength to the findings, results of our previous studies have shown that the prevalence of $\mathrm{H}$ ducreyi and the carriage of HSV in unselected men were both about $2 \%$ (Kinghorn, Hafiz, and Barton, unpublished observation).

Other potentially pathogenic aerobic bacteria were not common, a finding similar to those of most previous studies. $C$ albicans was isolated in appreciable amounts from a small proportion (16\%) of ulcers. The highly significant difference between the low $(6 \%)$ incidence of $C$ albicans in patients with HSV and the $31 \%$ incidence in non-herpetic ulcers may indicate that it causes some genital ulcers. This supports the findings of other workers that $C$ albicans can cause erosive lesions and is a primary pathogen in ulcers, particularly those secondary to minor trauma, such as the scratching associated with pruritis. ${ }^{20} 21$ The three associated strains of $H$ ducreyi were probably secondary pathogens (see below).

Anaerobic bacteria were isolated from a large proportion of ulcers, both herpetic and non-herpetic. There was no evidence that they had caused the ulcerative lesions, but they were probably more than normal commensals merely colonising the damaged area. The most common anaerobes isolated were asaccharolytic bacteroides ( $B$ asaccharolyticus and $B$ ureolyticus). These may be found in small numbers in the normal female genital tract, ${ }^{15}$ but they are being recognised increasingly as important pathogens in various superficial necrotising lesions, such as perianal and perineal abscesses, ${ }^{22-24}$ sebaceous cysts ${ }^{23}$ and abscesses in the non-lactating breast, ${ }^{25}$ decubitus and varicose ulcers, ${ }^{26}$ and diabetic gangrene. ${ }^{29}$ In most of these conditions the anaerobes do not necessarily cause, but appear to affect the continued development of, lesions and the spreading tissue destruction, and they are probably at least secondary pathogens in genital ulcers. The argument is less clear for the melaninogenicus-oralis group of bacteroides. These are normal vaginal commensals, but have also been recognised as potential, perhaps secondary, pathogens in infections close to their normal habitats in the mouth and genital tract, such as dental and facial abscesses, ${ }^{28}$ chronic otitis media ${ }^{29}$ and otogenic brain abscesses, ${ }^{30}$ and puerperal and postabortal infections of the uterus. ${ }^{31}$

Improved methods of isolating and identifying anaerobic bacteria in the microbiology laboratory have shown that they may affect a large proportion of genital ulcers. This finding raises the question of whether specific treatment should be aimed at these organisms. Anaerobes have not been considered in most work on treating genital ulcers, but this does not seem to have affected the clinical outcome. Normally, attention to good hygiene and frequent saline bathing of the ulcerative lesions will remove the environmental conditions in which the anaerobes flourish, and specific treatment may not be necessary. Some patients with clinical chancroid, however, develop the important complication of suppurative inguinal buboes. Examination of fluid from buboes often fails to disclose $H$ ducreyi, and examination of bubo fluid by more careful methods may be advisable. At other sites, such as those of decubitus and varicose ulcers and diabetic gangrene, chemotherapy aimed specifically at the anaerobic bacteria in addition to normal superficial cleansing methods may increase the speed of healing.

The results of the study reported here suggest that anaerobes are implicated in the pathogenesis, if not the cause, of genital ulcers. This is similar to our previous finding that $H$ ducreyi is a secondary pathogen in a large proportion of genital ulcers although not the cause of ulceration in our patients, a conclusion which is supported by the findings of other workers. ${ }^{32}$ It is important that further studies should now be undertaken to examine the prevalence of $\boldsymbol{H}$ ducreyi, $\boldsymbol{C}$ albicans, and anaerobes in ulcers unrelated to HSV infection, and to compare the effect of treatment with metronidazole on the healing time of herpetic and non-herpetic ulcers.

We thank the medical and nursing staff of the department of genitourinary medicine for collecting the specimens and recording the patients' data and Mrs Hazel Bland for typing the manuscript.

\section{References}

1. Sexually transmitted diseases: extract from the annual report of the Chief Medical Officer of the Department of Health and Social Security for the year 1981. British Journal of Venereal Diseases 1983;59:206-10. 
2. Duncan MO, Bilgeri YR, Fehler HG, Ballard RC. The diagnosis of sexually acquired ulcerations in black patients in Johannesburg. South African Journal of Sexually Transmitted Diseases 1981;1:20-3.

3. Nsanze H, Fast MV, D'Costa LJ, Tukei P, Curran J, Ronald AR. Genital ulcers in Kenya: clinical and laboratory study. British Journal of Venereal Diseases 1981;57:378-81

4. Hammond GW, Slutchuk M, Scatliff J, Sherman E, Wilt JC, Ronald AR. Epidemiological, clinical, laboratory and therapeutic features of an urban outbreak of chancroid in North America. Rev Infect Dis 1980; 2:867-79.

5. Kinghorn GR, Hafiz S, McEntegart MG. Pathogenic microbial flora of genital ulcers in Sheffield with particular reference to herpes simplex virus and Haemophilus ducreyi. British Journal of Venereal Diseases 1982;58:377-80.

6. Meheus A, Van Dyck E, Friedman F. Genital infections in Swaziland. Ann Soc Belg Med Trop 1982;62:361-7.

7. Randall A. Idiopathic gangrene of the scrotum. J Urol 1920; 4:219-35.

8. Meleney FL. A differential diagnosis between certain types of infectious gangrene of the skin: with particular reference to haemolytic streptococcus gangrene and bacterial synergistic gangrene. Surg Gynecol Obstet 1933;56:847-67.

9. Chapel T, Brown WJ, Jeffries C, Stewart JA. The microbiological flora of penile ulcerations. J Infect Dis 1978;137: 50-6.

10. Masfari AN, Kinghorn GR, Duerden BI. Anaerobes in genitourinary infections in men. British Journal of Venereal Diseases 1983;59:255-9.

11. Amies CR. A modified formula for the preparation of Stuart's transport medium. Can J Public Health 1967;58:296-300.

12. Kinghorn GR, Hafiz S, McEntegart MG. Modified haemin containing medium for the isolation of $H$ ducreyi. Lancet 1982; i: 393 .

13. Hafiz S, McEntegart MG, Kinghorn GR. Sheffield medium for cultivation of Haemophilus ducreyi. British Journal of Venereal Diseases 1984;60: 196-8.

14. Holbrook WP, Ogston SA, Ross PW. A method for the isolation of Bacteroides melaninogenicus from the human mouth. J Med Microbiol 1978;11:203-7.

15. Duerden BI. The isolation and identification of Bacteroides spp from the normal human vaginal flora. J Med Microbiol 1980; 13: 79-87.
16. Mallard RH, Macaulay ME, Riodan T, Chowdhury FH, Chandiok S, Bhattacharyya MN. Haemophilus ducreyi infection in Manchester. Lancet 1983; ii: 283.

17. Forster GE, Karim QN, White KB, Harris JRW. Isolating Haemophilus ducreyi. Lancet 1983; ii:910.

18. Sprott MS, Pattman RS, Richardson IR, Schofield CBS, Saravanamutto KM. Haemophilus ducreyi and genital ulcers. Lancet 1983;ii: 1302-3.

19. Kinghorn GR, Hafiz S. Sheffield isolates are Haemophilus ducreyi. Lancet 1983; ii: 1079.

20. Catterall RD. Candida albicans and the contraceptive pill. Lancet 1966; ii: 830-1.

21. Hurley R. Recurrent Candida infection. Clin Obstet Gynecol 1981;8:209-14

22. Duerden BI. The identification of Gram-negative anaerobic bacilli isolated from clinical infections. Journal of Hygiene (Cambridge) 1980;84:301-13.

23. Duerden BI, Bennet KW, Faulkner J. Isolation of Bacteroides ureolyticus (B corrodens) from clinical infections. $J$ Clin Pathol 1982; 35:309-12.

24. Meislin HW, Lerner SA, Graves MH, et al. Cutaneous abscesses: anaerobic bacteriology and outpatient management. Ann Intern Med 1977;87:145-9.

25. Pearson HE. Bacteroides in areolar breast abscesses. Surg Gynecol Obstet 1967;125:800-2.

26. Chow AW, Galpin JE, Guze LB. Clindamycin for treatment of sepsis caused by decubitus ulcers. J Infect Dis 1977;135 suppl: S65-S68.

27. Fierer J, Daniel D, Davis C. The fetid foot: lower extremity infections in patients with diabetis mellitus. Rev Infect Dis 1979; 1:210-7.

28. Chow AW, Roster SM, Brady FA. Orofacial odontogenic infections. Ann Intern Med 1978; 88:392-402.

29. Brook I, Finegold SM. Bacteriology of chronic otitis media. JAMA 1979; 241:487-8

30. Ingham HR, High AS, Kalbag RM, Sengupta RP, Tharangonnet D, Selkon JB. Abscesses of the frontal lobe of the brain secondary to covert dental sepsis. Lancet 1978; ii: 497-9.

31. Willis AT. Anaerobic bacteriology: clinical and laboratory practice. London: Butterworth, 1977.

32. Sullivan M. Chancroid. American Journal of Syphilis, Gonorrhea and Venereal Diseases 1940;24:482-521. 